Ekuitas: Jurnal Pendidikan Ekonomi

Volume 9, Number 1, Tahun 2021, pp. 50-59

P-ISSN : 2354-6107E-ISSN : 2549-2292

DOI : $10.23887 /$ ekuitas.v9i1.26756

Open Access: https://ejournal.undiksha.ac.id/index.php/EKU

\title{
Non Performing Loan, Loan to Deposit Ratio, Good Corporate Governance, Net Interest Margin, Return on Assets, Capital Adequacy Ratio dan Economic Value Added Terhadap Harga Saham
}

\author{
Kadek Ayu Supriatini ${ }^{*}$, Ni Luh Gede Erni Sulindawati²
}

1,2,Universitas Pendidikan Ganesha, Singaraja - Indonesia

\begin{tabular}{l} 
A R T I C L EI N F O \\
\hline Article history: \\
Received July, 152020 \\
Received in revised form \\
May, 192021 \\
Accepted May, 252021 \\
Available online June, 28 \\
2021 \\
Kata Kunci: \\
Economic value added, \\
harga saham, RBBR. \\
Keywords: \\
Economic value added, \\
RBBR, stock prices.
\end{tabular}

\begin{abstract}
A B S T R A K
Perbankan merupakan salah satu perusahaan yang memiliki peranan sebagai penopang perekonomian. Secara konseptual tujuan dari penelitian untuk mengamati kinerja keuangan. Untuk mengetahui kesehatan perbankan digunakan rasio-rasio keuangan melalui pendekatan Risk Based Bank Rating (RBBR) serta melalui alat nilai kinerja dengan pendekatan Ecconomic Value Added. Dengan demikian hasil penelitian ini dimaksudkan untuk mengetahui pengaruh Non Performing Loan, Loan to Deposit Ratio, Good Coorporate Governance, Net Interest Margin, Return On Asset, Capital Adequacy Ratio, dan Economic Value Added terhadap Harga Saham Bank. Penelitian jenis ini adalah dengan menggunakan penelitian kuantitatif karena penggunaan datanya berbentuk angka. Perolehan data ialah bersifat sekunder melalui laporan keuangan. Penggunaan populasinya yaitu keseluruhan bank yang listing di Bursa Efek Indonesia khusus periode 2014-2018. Cara pengambilan sampel dengan purposive sampling melalui beberapa kriteria tertentu. Jumlah sampel yang
\end{abstract} dihasilkan sejumlah 23 bank dalam lima tahun. Pengolahan data menggunakan teknik regresi linier berganda melalui program SPSS versi 20.

Hasil penelitian menunjukan bahwa secara parsial terdapat pengaruh negatif variabel Non Performing Loan, Loan to Deposit Ratio, Good Coorporate Governance terhadap Harga Saham,sedangkan variabel Net Interest Margin, Return On Asset, Economic Value Added berpengaruh positif terhadap Harga Saham. Sementara, Capital Adequacy Ratio tidak berpengaruh terhadap Harga Saham

\section{A B S T R A C T}

Banking is one of the companies that have the role to support the economy. Conceptually the purpose of the research is to observe financial performance. To find out the health of banks, financial ratios are used through the Risk Based Bank Rating (RBBR) approach and through the performance value tool with the Ecconomic Value Added approach. Thus the results of this study are intended to determine the effect of Non Performing Loan, Loan to Deposit Ratio, Good Coorporate Governance, Net Interest Margin, Return On Asset, Capital Adequacy Ratio and Economic Value Added on the Bank's Stock Price. This type of research is to use quantitative because the use of data is in the form of numbers. Data acquisition is secondary in the financial statements. population use, namely overall listing on the Indonesia Stock Exchange specifically for the period 2014-2018. Sampling by purposive sampling through certain criteria. The number of samples produced was 23 banks in five years. Data processing using multiple linear regression techniques through SPSS version 20. The results showed that partially there were negative influences of NonPerforming Loans, Loan To Deposit Ratio, Good Corporate Governance variables on Stock Prices, while Net Interest Margin, Return On Assets, and Economic Value Added variables had positive effects on Stock Prices. While the Capital Adequacy Ratio has no effect on the Share Price.

\footnotetext{
*Corresponding author.

E-mail : ayusupriatini2701@gmail.com (Kadek Ayu Supriatini)
} 


\section{Pendahuluan}

Saham adalah jenis investasi dalam bentuk surat berharga dengan risiko cukup tinggi yang banyak diminati dikalangan investor. Salah satu saham yang memiliki tingkat likuid yang baik adalah saham pada sektor perbankan (kontan.co.id, 2018). Walaupun demikian, harga saham perbankan tidak terlepas dari fluktuasi yang sering terjadi dari tahun ke tahun yang berpengaruh terhadap penurunan harga saham perbankan. Seperti hal nya Pada tahun 2018, Indeks Harga Saham Gabungan (IHSG) terus merosot hingga sebesar 9,58\%, penurunan indeks ini mempengaruhi kapitalisasi pasar saham atau market capitalization. Penurunan pasar saham pada Saham sektor perbankan mengalami penurunan yang cukup besar. Penurunan ini terjadi seiring kebijakan bank Indonesia menaikan suku bunga acuan untuk tetap menjaga stabilitas khususnya stabilitas nilai tukar rupiah (kontan.co.id, 2018). Berdasarkan jumlah populasi sebesar 36 perbankan dalam penelitian ini, 32 bank mengalami penurunan harga saham periode 2014-2018, yang terdiri dari bank yang berkode saham AGRS, BMAS, AGRO, BBKP, BABP, BDMN, BBMD, BBNI, BBRI, BEKS, BINA, BJTM, BKSW, BNGA, BNII, BNLI, BTPN, BVIC, DNAR, INPC, MCOR, MEGA, NISP, MEGA, BMRI, NOBU, PNBS, PNBN, BNBA, PNBN, SDRA, sedangkan sisanya hanya 4 perbankan yang mengalami kenaikan harga saham berturut-turut yang terdiri dari bank yang berkode saham BACA, MAYA, BCIC, dan BBCA. Penurunan harga saham perbankan yang terjadi pada 32 bank tersebut merupakan masalah yang serius bagi perkembangan perusahaan perbankan kedepannya. Jika penurunan tersebut terus terjadi tanpa adanya manajemen yang memadai maka kinerja bank tersebut akan mendapati penurunan yang akan berimbas pada kontinuitas usaha dari perbankan itu sendiri.Selain karena faktor eksternal seperti tingkat inflasi, suku bunga, kondisi perekonomian, perang dagang, serta kurs rupiah yang menyebabkan perubahan harga saham pada perusahaan perbankan, faktor internal juga menjadi salah satu pemicu dari kenaikan atau penurunan harga saham. Salah satunya dapat dilihat dari bagaimana kemampuan manajemen dalam menghasilkan kinerja yang baik. Karena seorang investor yang akan berinvestasi, terlebih dahulu akan melakukan evaluasi terhadap emiten yang akan ditanamkan modalnya. Oleh karena itu, hal tersebut akan mendorong perusahaan khususnya perbankan untuk bisa terus meningkatkan kinerja dan menciptakan nilai yang lebih baik bagi perusahaannya. Untuk mengukur baik buruknya kinerja keseluruhan suatu bank dapat digunakan melalui penganalisaan kesehatan bank tersebut dengan pengukuran rasio keuangan bank. Selain pemakaian rasio bank, Economic value added (EVA) juga ialah penilaian kinerja yang paling efektif digunakan terutama bagi kepentingan investor, karena EVA memberikan gambaran mengenai nilai tambah ekonomis suatu bank akibat adanya suatu aktivitas atau strategi manajemen bank (Silalahi dan Tamba (2017).

Berlandaskan regulasi Bank Indonesia No. 13/1/PBI/2011, bank mempunyai kewajiban untuk menilai kesehatannya menggunakan pendekatan yang berbasis risiko (RBBR) dengan 4 faktor penilaian risiko yaitu Profil Risiko (Risk Profile), Good Corporate Governance (GCG), Rentabilitas (Earning), dan Permodalan (Capital). Pada penelitian ini fokus utama yang dijadikan perhitungan terkait profil risiko adalah kredit risiko dan likuiditas. Alasannya karena kredit risiko ialah pendapatan utama yang diperoleh bank yang berpengaruh terhadap kinerja yang dihasilkan bank. Sedangkan alasan menggunakan rasio likuiditas karena rasio tersebut menunjukan usaha perbankan dalam melunasi kewajiban yang telah jatuh tempo atas asset likuidnya, jika bank tidak mampu menggunakan asset likuidnya untuk membiayai kegiatan operasionalnya maka mencerminkan kondisi keuangan bank tidak baik. Penilaian tingkat kesehatan akan dilaksanakan pada tiap-tiap variabel yang termasuk ke dalam faktor Risk Based Bank Rating (RBBR). Disamping itu penghitungan hasil kinerja bank juga dapat diukur menggunakan konsep Economic value added (EVA). Dibawah ini ialah tiap-tiap variabel yang dipakai pada penelitian ini yang dapat dipaparkan antara lain:

Non Performing Loan (NPL) adalah rasio yang menganalogikan seluruh pinjaman yang bermasalah dengan besarnya seluruh pinjaman yang oleh perbankan salurkan untuk debitur. Kredit bermasalah disebabkan karena adanya ketidaklancaran dalam pemenuhan pokok pinjaman dan bunga sehingga dapat memepengaruhi penurunan kinerja bank. Non Performing Loan (NPL) menerangkan seberapa besar perbankan dalam menanggung risiko atas kredit yang dihasilkan. Jika risiko kredit yang dimiliki bank tinggi maka menyebakan tingkat keuntungan akan menurun sehingga harga perbankan akan mengalami penurunan atas harga sahamnya, oleh karena itu dikatakan bahwa terdapatnya pengaruh negatif NPL atas harga saham(Istanti dan Rahmawati, 2012). Hal ini dinyatakan pula dalam penelitian Martonorika (2017), Sari, Yanti, dan Zulbhari (2018), dimana Non Performing Loan pengaruhnya bersifat negatif atas harga saham. Berlandaskan pemaparan diatas, adapun hipotesis pertama yang diajukan peneliti:

H1 : Non Performing Loan berpengaruh negatif terhadap harga saham.

Loan to Deposit Ratio (LDR) menilai usaha bank untuk memenuhi pembayaran atas pendanaan yang diperoleh dari masyarakat atas pengambilan kredit yang telah tersalurkan, kemudian dilakukan perbandingan dengan keseluruhan dana dari masyarakat serta modal individu dari suatu bank (Kasmir, 
2012). Tingginya nilai LDR menyebabkan semakin rendah likuiditas bank, karena pembiayaan terhadap kredit akan semakin besar sehingga mengakibatkan terjadinya penurunan pada harga saham (Sari, Yanti, dan Zulbhari, 2018). Hal ini dinyatakan juga atas penelitian yang telah dijalankan Martonorika (2017) menyimpulkan bahwa Loan to Deposit Ratio (LDR) mempunyai pengaruh yang negatif atas harga saham. Berlandaskan pemaparan diatas, hipotesis kedua yang diajukan peneleiti :

H2 : Loan to Deposit Ratio berpengaruh negatif terhadap harga saham.

Penilaian atas indikator GCG bermaksud untuk menguji usaha manajemen bank menerapkan asasasas mengenai tata kelola perusahaan dengan baik. Penilaian GCG dalam penelitian ini menggunakan peringkat GCG, dimana peringkat terendah 1 yang memiliki arti sangat baik dan peringkat tertinggi 5 yang mempunyai arti kurang baik. Sehingga semakin rendah peringkat yang dihasilkan bank maka semakin baik tata kelola bank. Semakin rendah peringkat GCG menggambarkan kesehatan dan kinerja bank yang sangat baik, tentunya hal ini akan menaikan harga saham bank tersebut. Sebaliknya, jika bank memiliki peringkat peringkat GCG yang tinggi, menandakan bahwa kinerja bank tersebut kurang baik sehingga berimbas pada harga saham bank yang menurun (Affandi, 2017). Hal ini dinyatakan juga dalam penelitian Setyawan (2012) menunjukan bahwa Good Corporate Governance bersifat negatif pengaruhnya atas harga saham perbankan. Berdasarkan paparan diatas, adapun hipotesis ketiga yang diajukan peneliti:

H3 : Good Corporate Governance (GCG) berpengaruh negatif terhadap harga saham.

Net Interest Margin (NIM) menilai usaha perbankan mengenai pengelolaannya terhadap asset yang bersifat produktif (kredit) untuk memperoleh suatu pendapatan bersih atas bunga (Cahyani dan Putri, 2018).Jika nilai Net interest Margin tinggi, maka tingkat untung yang diperoleh melalui pendapatan yang berasal dari bunga akan berbanding lurus dengan pergerakan harga sahamnya (Febiola, 2019). Hal ini juga dinyatakan dalam penelitian Cahyani dan Putri (2018) bahwa Net Interest Margin (NIM) bersifat positif pengaruhnya atas perubahan harga saham bank. Berlandaskan pemaparan diatas, maka hipotesis keempat yang peneliti ajukan :

H4 : Net Interest Margin berpengaruh positif terhadap harga saham.

Return On Asset (ROA) mencakup penilaian laba terhadap jumlah keseluruhan assets. Jika nilai ROA semakin meningkat, maka semakin baik kesehatan bank tersebut, sehingga meningkatkan efektifitas bank dalam mencapai laba. Dengan demikian investor akan semakin yakin dalam memilih investasi di suatu bank dan tentunya hal ini akan memiliki dampak yang baik atas kenaikan harga saham di bursa efek (Cahyani dan Putri, 2018). Hal ini dinyatakan juga dalam penelitian Purnamasari, Nuraina, dan Astuti (2017) yang menunjukan bahwa Return On Asset (ROA) bersifat positif dan signifikan pengaruhnya atas harga saham bank. Berlandaskan paparan diatas, hipotesis keempat yang diajukan peneliti:

H5 : Return On Asset berpengaruh positif terhadap harga saham.

Capital Adeque Ratio (CAR) memperlihatkan berapa besar kelengkapan modal minimal yang mampu dihasilkan untuk membentangi akibat adanya kerugian dari aktiva-aktiva yang memiliki risiko. Nilai CAR yang tinggi mencerminkan kondisi perbankan yang sehat dan mampu menjamin permodalannya dengan asset yang dimilikinya, sehingga investor akan lebih percaya untuk menyertakan modalnya pada bank yang sehat, sehingga harga saham perusahaan akan naik (Fahlevi, Asmapane, dam Oktavianti, 2018). Hal ini dinyatakan juga dalam penelitian Riyadi dan Setyawan (2017) yang membuktikan bahwa Capital Adequecy Ratio (CAR) mempunyai dampak yang positif atas harga saham. Berlandaskan paparan diatas, hipotesis kenam yang diajukan peneliti:

H6 : Capital Adequacy Ratio berpengaruh positif terhadap harga saham.

Economic value added (EVA) adalah alat untuk pengukuran kinerja, sehingga diketahui seberapa besar perusahaan bisa memperoleh tambahan nilai ekonomis melalui pengurangan biaya ats modal (cost of capital) yang diakibatkan terdapatnya kegiatan penanaman modal yang telah terjadi (Andriyani, 2015). Perusahaan perbankan dikatakan mampu menghasilkan nilai ekstra bagi penanam modal atau investor, jika EVA yang dihasilkan positif, yang artinya pengembalian atau return yang berhasil diperoleh perusahaan lebih tinggi dari biaya modal. Peningkatan nilai EVA yang terjadi terus menerus mempengaruhi peningkatan nilai pasar perusahaan, sehingga berdampak pula terhadap kenaikan nilai saham perusahaan (Silalahi dan Tamba, 2017). Hal ini dinyatakan juga dalam penelitian Thover (2018) yang membuktikan bahwa Economic value added (EVA) bersifat positif pengaruhnya atas harga saham. Berlandaskan penjabaran diatas, adapun hipotesis kenam yang diajukan peneliti:

H7 : Economic Value Added berpengaruh positif terhadap harga saham.

Analisis mengenai kesehatan bank maupun kinerja bank terhadap harga saham sangat penting dilakukan, karena kesehatan bank merupakan faktor utama yang dapat digunakan oleh bank dalam menilai hasil kinerjanya, selain itu dengan menggunakan alat penilaian kinerja yang efektif akan memberikan hasil yang lebih akurat selain menggunakan rasio keuangan bank. Dengan terjadinya penurunan harga saham perbankan pada periode 2014-2018 tersebut, maka bank harus dapat 
membenahi dan memperbaiki aspek kesehatannya yang dalam hal ini adalah kinerja keuangan bank tersebut maupun tata kelola bank agar dapat ditingkatkan. Meskipun faktor eksternal memiliki pegaruh yang lebih dominan dibandingkan faktor internal terhadap perubahan harga saham, namun setidaknya bank masih dapat mengendalikan faktor internalnya guna memperkecil risiko yang disebabkan oleh faktor eksternal tersebut.

Berdasarkan pemaparan dari uraian diatas, adapun tujuan yang ingin dicapai pada penelitian ini adalah untuk melihat Pengaruh Non Performing Loan, Loan To Deposit Ratio, Good Corporate Governance, Net Interest Margin, Return On Asset, Capital Adequacy Ratio dan Economic value added Terhadap Harga Saham Perusahaan Perbankan Yang Listing di Bursa Efek Indonesia Tahun 2014-2018”.

\section{Metode}

Penelitian ini merupakan jenis penelitian kuantitatif karena penggunaan datanya berbentuk angka. Data berasal dari data sekunder melalui perantara website www.idx.co.id dan website yang berasal dari perusahaan perbankan yang terkait dengan penelitian ini. Penggunaan populasinya ialah seluruh perbankan yang listing di Bursa Efek Indonesia tahun 2014-2018. Cara penarikan sampel dengan memakai purposive sampling menggunakan beberapa karakteristik yang spesifik, sehingga besarnya sampel yang dihasilkan 23 bank dalam jangka waktu 5 tahun. Teknik analisis data menggunakn SPSS versi 20. Data-data tersebut diuji dengan teknik regresi linier berganda, kemudian dilakukan pengujian, yang terdiri atas asumsi klasik (uji normalitas, uji multikolinearitas, uji heteroskedastisitas, uji auto korelasi) dan uji hipotesis (uji adjusted R square dan uji t).

\section{Hasil dan pembahasan}

Bagian pertama dari uji asumsi klasik ialah uji normalitas yang ditujukan untuk mendeteksi terdistribusi normal atau tidaknya dependen variabel dan independen variabel yang digunakan(Ghozali, 2011). Uji normalitas residual yang dipakai ialah One Sampel Kolmogrov-Smirnov Test mengacu pada taraf signifikansi 5\%. Suatu pola regresi disebut terdistribusi normal bila mempunyai signifikansi melebihi dari nilai 0,05 . Hasil yang didapat dari Uji normalitas dalam penelitian ini memperlihatkan hasil atas nilai sig yang diperoleh sebesar 0,476 , sehingga data atas variabel yang digunakan mempunyai distribusi normal, dimana nilai signifikannya lebih tinggi dari 0,05 .

Setelah uji normalitas, selanjutnya terdapat uji multikolinieritas yang ditujukan untuk mendapati adanya celah hubungan yang tinggi antara variabel bebas yang digunakan pada pola regresi. Adapun teknik yang dilakukan untuk mengetahui masalah multikolinieritas ialah dengan memahami hasil VIF dan tolerance yang diperoleh. Dimana, nilai VIF yang dihasilkan tidak boleh melebihi dari 10, serta nilai Tol yang dihasilkan tidak boleh dibawah 0,1 (Ghozali, 2011). Hasil uji multikolinieritas menunjukan bahwa nilai TOL variabel NPL 0,918, variabel LDR 0,802, variabel GCG 0,864, variabel NIM 0,584, variabel ROA 0,424, variabel CAR 0,798, variabel EVA 0,442. Selanjutnya nilai VIF NPL 1,089, variabel LDR 1,246, variabel GCG 1,157, variabel NIM 1,711, variabel ROA 2,361, variabel CAR 1,254, variabel EVA 2,261. Berlandaskan hasil uji multikolonieritas, dapat ditangkap atas perohelan hasil nilai TOL variabel melebihi nilai 0,1. Demikan juga dengan hasil VIF melalui tiap-tiap variabel memiliki nilai dibawah 10, dengan demikian bisa ditunjukan terkait regresi model ini telah lepas dari masalah multikolonieritas.

Setelah uji multikolonieritas, selanjutnya terdapat uji heteroskedastisitas. ditujukan untuk mengetahui terdapat atau tidak ketidaksamaan varians satu pemantauan ke pemantauan yang lain atas penggunaan pola regresi. Untuk mendeteksi adanya masalah heteroskedastisitas, maka dapat dialkukan dengan menganalisis grafik scatterplot. Adapun kriteria analisis yang digunakan menurut Ghozhali (2011). Apabila tidak adanya kejelasan ragam pola pada grafik, serta adanya pemerataan persebaran titik di atas dan bawah angka 0 dalam sumbu $\mathrm{Y}$, maka dinyatakan terlepas dari permasalahan heteroskedastisitas. 


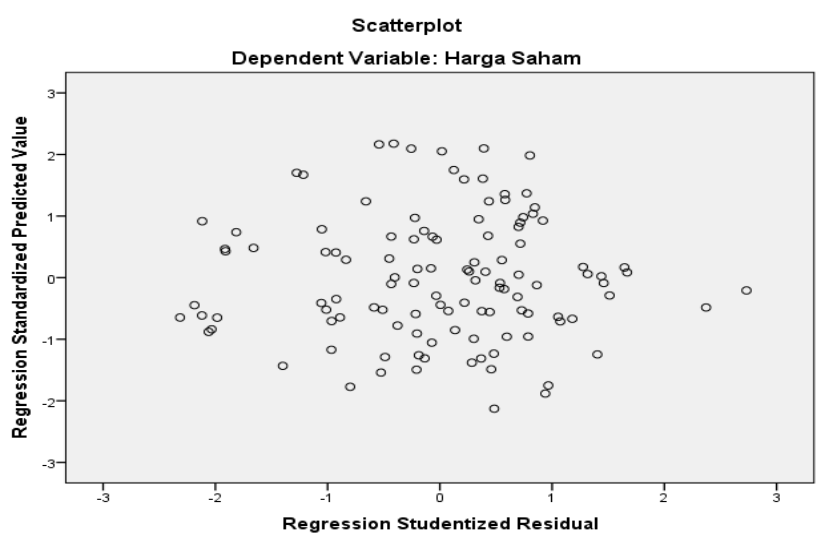

Gambar 1. Grafik Scatterplot

Sumber Data :Diolah, 2020

Sesuai grafik Scatterplot yang dihasilkan, yang ditunjukan pada gambar diatas, terlihat titi-titik tersebar merata dibawah dan diatas angka nol, Sehingga dinyatakan pada regresi model telah terlepas atas permasalahan heteroskedastisitas.

Setelah uji heteroskedastisitas, selanjutnya adalah uji autokorelasi yang ditujukan dalam mendeteksi tersedianya hubungan antara kekeliruan pengacau dalam waktu saat ini dengan kekeliruan pada waktu sebelumnya atau tidak atas penggunaan regresi model. Regresi l model dianggap baik jika telah terlepas dari permasalahan autokorelasi. Menurut Santoso (2012) dalam menggali ada korelasi atau tidak atas penggunaan regresi model, maka dijalankan melalui uji nilai Durbin Watson melalui kriteria, apabila letak hasil D-W diantara -2 hingga +2 artinya lepas dari auto korelasi. uji autokorelasi menghasilkan hasil Durbin watson sebesar 1,005, yang tergolong kriteria $-2<1,005<+2$, dengan demikan dinyatakan bahwa antar variabel terlepas dari auto korelasi karena nilai D-W melebihi dari -2 dan dibawah dari +2 .

Setelah selesai perlakuan uji asumsi klasik, berikutnya adalah uji hipotesis yang mencakup uji Adjusted R Square dan uji-t. agar dapat dideteksi pengaruh diantara variabel masing-masing $\mathrm{x}$ dan $\mathrm{y}$, dapat diketahui melalui parsial uji atau uji-t. berdasarkan hipotesis yang telah diajukan, perhitungan statistik disebut signifikan, bila H0 ditolak dan sedangkan disebut tidak signifikan bila H0 diterima (Sugiyono, 2014). Pola linier regresi yang ditujukan pada penelitian ini ialah menguji variabel NPL (X1), LDR (X2), GCG (X3), NIM (X4), ROA (X4), CAR (X5), EVA (X6) atas Harga Saham (Y). Dibawah ini ialah hasil regresi linier berganda pada tabel 1 berikut:

Tabel 1. Hasil Regresi Linier Berganda

\begin{tabular}{llrrrrr} 
& \multicolumn{2}{c}{$\begin{array}{c}\text { Unstandardized } \\
\text { Coefficients }\end{array}$} & \multicolumn{2}{c}{$\begin{array}{c}\text { Standardized } \\
\text { Coefficients }\end{array}$} & & \\
\cline { 2 - 4 } \multicolumn{1}{c}{ Model } & \multicolumn{1}{c}{$\mathrm{B}$} & \multicolumn{1}{c}{ Std. Error } & \multicolumn{1}{c}{ Beta } & \multicolumn{1}{c}{ T } & Sig. \\
\hline 1 (Constant) & 4.281 & 3.282 & & 1.304 & .195 \\
Non Performing Loan & -.161 & .060 & -.140 & -2.686 & .008 \\
Loan to Deposit Ratio & -1.810 & .659 & -.153 & -2.745 & .007 \\
Good Coorporate & -.374 & .187 & -.108 & -2.001 & .048 \\
Governance & & & & & \\
Net Interest Margin & .729 & .241 & .198 & 3.019 & .003 \\
Return On Asset & .316 & .133 & .183 & 2.382 & .019 \\
Capital Adequecy Ratio & -.095 & .156 & -.034 & -.609 & .544 \\
Economic Value Added & .310 & .039 & .605 & 8.043 & .000 \\
\hline
\end{tabular}

Sumber: Data diolah, 2020 
Sesuai dengan pengolahan data dengan teknik regresi linier berganda yang diperlihatkan dalam tabel 1, maka didapatkan regresi hasil melalui persamaan berikut:

$Y=4,281+-0,161(\mathrm{X} 1)+-1,810(\mathrm{X} 2)+-0,374(\mathrm{X} 3)+0,729(\mathrm{X} 4)+0.316(\mathrm{X} 5)+-0,095(\mathrm{X6})+0,310(\mathrm{X} 7)$ ..(1)

Berdasarkan kesamaan linier regresi yang telah disusun diatas, diketahui nilai konstanta yang diperoleh bernilai positif sebesar 4,281, yang artinya ketika independen variabel dianggap tetap, maka variabel dependen yaitu harga saham 4,281. Non Performing Loan memiliki koefision sebesar $-0,161$, artinya pengaruh variabel NPL bersifat negatif atas Harga Saham, dimana setiap naiknya NPL 1\%, maka turunnya harga saham 0,161 atau 16,1 \% dengan asumsi variabel lainnya tetap. Loan to Deposit Ratio (LDR) didapat koefision -1,810, maksudnya variabel LDR bersifat negatif atas Harga Saham, setiap LDR meningkat $1 \%$, maka harga saham menurun sebesar 1,810 atau 181\% dengan anggapan variabel lainnya tetap. Good Corporate Governance (GCG) didapat koefisien - 0,374 , maksudnya variabel GCG bersifat negatif atas Harga Saham, dimana setiap peringkat GCG meningkat 1\%, maka turunnya harga saham 0,374 atau 37,4\% dengan anggapan variabel lainnya tetap. Net Interest Margin (NIM) didapati koefisien sebesar 0,729 , berarti ada pengaruh NIM yang bersifat positif atas variabel Harga Saham, ketika NIM tumbuh $1 \%$ maka harga saham juga tumbuh 0,729 atau $72,9 \%$ dengan asumsi variabel lainnya tetap. Return On Asset (ROA) didapati koefisien 0,316, maksudnya adanya pengaruh positif variabel ROA atas Harga Saham, setiap meningkat $1 \%$ ROA maka harga saham tumbuh ke 0,316 atau $31,6 \%$ dengan asumsi variabel lainnya tetap. Capital Adequacy Ratio (CAR) memiliki koefisien -0,095 artinya ada pengaruh negatif variabel CAR terhadap Harga Saham, dimana setiap rasio CAR tumbuh 1\%, harga saham akan turun 0,095 atau 9,5\% dengan anggapan variabel lainnya tetap.

Selanjutnya dilakukan statistik uji t agar diketahui seberapa dominan pengaruh independen variabel secara individu terhadap dependen variabel (Gozhali, 2011). Untuk mencari t tabel, sebelumnya harus diketahui nilai $\mathrm{df}$ melalui rumus $\mathrm{df}=\mathrm{N}-\mathrm{k}$, taraf signifikan 0,05 diperoleh melalui tabel statistik. Sehingga diperoleh perhitungan, $\mathrm{Df}=115-7=108$, dengan taraf nyata 0,05 , sehingga $\mathrm{t}$ tabel yang didapat ialah 1,98217. Pengambilan dasar atas kesimpulan dalam penelitian, jika $\mathrm{t}$ hitung $<\mathrm{t}$ tabel, maka $\mathrm{Ha}$ ditolak dan H0 diterima, dan sebaliknya jika t hitung $>\mathrm{t}$ tabel, maka Ha diterima dan H0 ditolak. Sementara itu, kriteria atas keputusan yang diambil dapat dilihat melalui hasil sig, dengan kriteria, jika hasil sig > 0,05 maka Ha diterima dan HO ditolak, dan jika hasil sig < 0,05 maka Ha ditolak dan H0 diterima. Berdasarkan uji-t yang telah dihasilkan yang ditunjukan dalam tabel 1 diatas, dapat diamati pada keenam independen variabel yang mencakup dari variabel NPL, LDR, GCG, NIM, ROA, EVA mempunyai hasil t-hitung melebihi dari hasil t-tabel dan hasil sig dibawah dari 0,05, dengan demikian variabel masing-masing tersebut dinyatakan ada pengaruh secara signifkan terhadap harga saham. Sementara 1 independen variabel lainnya yaitu Capital Adequacy Ratio memiliki hasil t-hitung dibawah dari t-tabel, dan hasil signifikansi memelebihi 0,05, maka dari itu variabel Capital Adequacy Ratio dinyatakan tak adanya pengaruh atas harga saham. Sementara itu, arah pengaruhnya pada variabel Non Performing Loan (NPL), Loan to Deposit Ratio (LDR), Good Corporate Governance (GCG) bertanda negatif. Sedangkan Net Interest Margin (NIM), Return On Asset (ROA), Economic Value Added (EVA) bertanda positif.

\section{Non Performing Loan (NPL) mempunyai pengaruh negatif terhadap Harga Saham}

Non Performing Loan (NPL) ialah alat untuk menganalisis risiko bank yang menunjukan tingginya persentase permasalahan kredit yang dialami bank. Penyebab dari permasalahan kredit pada bank disebabkan karena adanya ketidaklancaran pembayaran kredit dari debitur yang harus segera dilunasi Dengan nilai NPL yang tinggi menandakan kredit bermasalah yang ada pada akan tinggi pula, sehingga akan mempengaruhi kesehatan bank tersebut, selain itu risiko yang ditanggung bank juga akan tinggi khususnya dalam hal biaya pencadangan kredit bermasalah akan makin besar. Tingginya NPL akan berdampak pula terhadap penurunan kinerja bank, sehingga akan memengaruhi investor enggan untuk menanam modal terhadap perbankan yang mempunyai NPL tinggi. Sesuai dengan teori sinyal bahwa kenaikan NPL ialah sinyal yang negatif bagi kenaikan harga atas saham perbankan. artinya, adanya minat yang rendah dari investor untuk memiliki saham sehingga terjadi penurunan atas nilai saham. Dengan demikian, hasil penelitian ini mendapat dukungan berlandaskan teori sinyal. Semakin besar hasil Non Performing Loan (NPL) maka berimbas atas turunnya harga saham perbankan, dimana investor merespon dengan tanggapan negatif yang akan mempengaruhi kondisi pasar. Hal ini dapat diamati dari harga saham bank yang menurun. 
Penelitian ini searah dengan hasil penelitian Martonorika (2018), Sari, Yanti dan Zulbhari (2018), Riyadi dan Setyawan (2018) yang menyatakan bahwa variabel Non Performing Loan (NPL) berpengaruh negatif dan signifikan terhadap Harga Saham.

\section{Loan to Deposit Ratio (LDR) berpengaruh negatif terhadap Harga Saham}

Loan to Deposit Ratio (LDR) ialah pengukuaran yang ditujukan untuk menilai besarnya pinjaman yang sudah tersalurkan dari bank dibandingi terhadap keselurhan dana nasabah yang mampu dikumpulkan bank. nilai LDR yang besar menandakan pinjaman yang tersalurkan oleh bank juga semakin besar. dibandingkan dengan keselurhan dana nasabah yang mampu dikumpulkan bank, sehingga likuiditas perbankan akan mengalami penurunan. Selain itu dengan pertumbuhan tingginya LDR akan menyebakan bank menanggung risiko yang besar pula, sedangkan disisi lain bank memiliki likuiditas yang rendah, sehingga menyebabkan perbankan kesulitan dalam menyediakan dana untuk membiayai kegiatan operasionalnya, baik dalam hal menyalurkan pinjaman kepada debitur lain, pelunasan utang kepada nasabah maupun pembayaran deviden kepada investor. Hal tersebut akan mempengaruhi kesehatan perbankan dan menyebakan kinerja bank akan semakin menurun. Sesuai dengan teori sinyal bahwa kenaikan Loan to Deposit Ratio (LDR) ialah sinyal negatif bagi kenaikan nilai saham bank. Hal ini berarti, terjadi penurunan minat investor akan saham bank sehingga adanya saham dengan harga yang menurun.

Hasil penelitian ini searah dari penelitian Martonorika (2018), Sari, Yanti dan Zulbhari (2018), Fahlevi, Asmapane, dan Oktavianti (2018) yang menyimpulkan bahwa variabel Loan to Deposit Ratio (LDR) berpengaruh negatif dan signifikan terhadap Harga Saham.

\section{Good Corporate Governance (GCG) berpengaruh negatif terhadap Harga Saham}

Good Corporate Governance (GCG) ialah sebuah mekanisme dan pola yang dipakai oleh orang-orang yang berkepentingan untuk meningkatkan akuntabilitas dan keberhasilan usaha. Dalam penelitian ini tata kelola bank dinilai dengan perankingan GCG yang dikelompokan dari ranking 1-5, dengan predikat mulai dari sangat baik, baik, cukup hingga tidak baik. Semakin tinggi peringkat GCG perbankan semakin buruk tata kelola perusahaan yang diterapkan oleh perbankan berdasarkan prinsip-prinsip GCG. Sebaliknya semakin kecil peringkat GCG maka semakin baik tata kelola yang berhasil diterapkan oleh perbankan sehingga kinerja perbankan mengalami peningkatan, dalam hal ini manajemen berhasil dalam mengelola perbankan dengan baik sehingga meminimalisir tindakan kurang tepat yang dilakukan oleh pihak dalam perusahaan. Sesuai dengan teori sinyal bahwa kenaikan peringkat Good Corporate Governance (GCG) menandakan adanya sinyal yang negatif bagi kenaikan harga saham perbankan. Hal ini berarti, terjadi penurunan minat investor akan saham sehingga harga saham juga menurunan. Oleh karena itu, hasil penelitian ini didukung oleh teori sinyal. Semakin tinggi peringkat Good Corporate Governance (GCG) maka terjadi harga saham yang turun, dimana investor akan merespon dengan sinyal negatif yang akan mempengaruhi kondisi pasar. Hal ini dapat terlihat dari turunnya harga saham bank .

Hasil penelitian ini juga searah berdasarkan penelitian Afandi (2017) dan Setyawan (2012) yang menyimpulkan bahwa variabel Good Corporate Governace berpengaruh negatif dan signifikan terhadap Harga Saham.

\section{Net Interest Margin (NIM) berpengaruh positif terhadap Harga Saham}

Net Interest Margin (NIM) ialah penggunaan rasio untuk menilai pencapaian pihak internal bank untuk meraih pemasukan profit atas bunga yang terlihat dari kemampuan bank dalam menyalurkan kreditnya. Besarnya nilai NIM sebagai tanda bahwa pendapatan yang berasal dari bunga bersih juga tinggi, sehingga pengelolaan atas aktiva produktif bank melalui kredit dapat dikatakan baik, serta kesehatan perbankan juga akan semakin baik. Sesuai dengan teori sinyal bahwa kenaikan nilai Net Interest Margin (NIM) ialah sinyal yang positif bagi kenaikan harga saham perbankan. Hal ini berarti, terjadi kenaikan permintaan saham dari investor sehingga terjadi harga saham yang naik. Dengan demikian, teori sinyal mendukung hasil penelitian ini. Semakin tinggi nilai nilai Net Interest Margin (NIM) maka terjadi penumbuhan harga saham bank, dimana investor akan menanggapi dalam bentuk sinyal positif yang akan mempengaruhi kondisi pasar yang dapat diamati melalui harga saham bank yang naik

Hasil penelitian ini juga searah dari penelitian yang dihasilkan Cahyani dan Putri (2018), Febiolla (2019) dan Setyawan (2012) yang menyimpulkan bahwa variabel Net Interest Margin berpengaruh positif terhadap Harga Saham.

\section{Return On Asset (ROA) berpengaruh positif terhadap Harga Saham}

Rasio Return On Asset (ROA) menunjukan profitabilitas yang berhasil diperoleh bank atas penggunaan asset yang dimiliki. nilai ROA tinggi memperlihatkan bahwa laba bank juga tinggi, sehingga kesehatan dan kinerja bank akan tinggi pula. Dengan pertumbuhan profitabilitas yang semakin meningkat 
maka akan berimbas terhadap return atau deviden yang diterima oleh pemodal. Investor maupun calon akan memberikan sinyal yang positif terhadap kenaikan ROA, hal ini bisa diamati dari naiknya harga saham bank, karena semakin tinggi keinginan investor untuk memperbanyak saham perbankan, maka harga saham bank juga akan tumbuh. Sesuai dengan teori sinyal bahwa kenaikan nilai Return On Asset (ROA) ialah sinyal positif atas kenaikan harga saham perbankan. Hal ini berarti, terjadi kenaikan permintaan saham dari investor yang membuat naiknya harga saham bank.

Hasil penelitian searah berdasarkan penelitian dari Cahyani dan Putri (2018), Purnamasari, Nuraina, dan Astuti (2017), dan Hendrayana dan Yasa (2015) yang menyatakan bahwa variabel Return On Assets berpengaruh positif terhadap Harga Saham.

\section{Capital Adequacy Ratio (CAR) tidak berpengaruh terhadap Harga Saham}

Berdasarkan penelitian yang telah dihasilkan diketahui bahwa tidak terdapat pengaruh CAR atas harga saham, karena hasil t-hitung yang diperoleh dibawah dari t-tabel dan hasil signifikansi variabel CAR melebihi 0,05. Maka dari itu, hipotesis yang sudah diajukan sebelumnya telah ditolak.

Capital Adeque Ratio (CAR) menunjukan seberapa besar kelengkapan modal minimal yang mampu dihasilkan untuk membentangi akibat adanya kerugian dari aktiva-aktiva yang memiliki risiko.Hasil ratarata CAR ialah 21\% yang sudah melampui batas minimal atas ketentuan dari bank Indonesia. Dengan demikian kondisi permodalan masing-masing bank berada dalam kondisi yang sehat. Pengawasan yang ketat dari Bank Indonesia terkait dengan batas minimum kecukupan modal bank membuat bank akan selalu dalam kondisi yang baik dalam pengelolaan modalnya. Sehingga investor tidak terlalu memperhatikan nilai CAR dalam berinvestasi pada perusahaan perbankan sehingga tidak adanya pengaruh CAR atas harga saham.

Hasil penelitian ini searah dengan penelitian Cahyani dan Putri (2018), Afandi (2017), dan Setyawan (2012) yang menyimpulkan bahwa variabel Capital Adequacy Ratio (CAR) tidak berpengaruh terhadap Harga Saham.

\section{Economic Value Added (EVA) berpengaruh positif terhadap Harga Saham.}

Konsep EVA ialah alat penilai kinerja yang efektif jika dipakai dalam mengukur nilai perusahaan, karena memasukan biaya modal yang didapat dari biaya pinjaman maupun ekuitas. Maka dari itu, konsep EVA ini merupakan penciptaan nilai tambah ekonomis yang berhasil diciptakan oleh perbankan melalui investasi yang dilakukan guna menciptakan kesejahteraan bagi pemegang saham dan sesuai dengan harapan para investor. Dengan EVA yang positif dan semakin meningkat, maka akan memikat keinginan investor maupun calon untuk menaruh modalnya pada perusahaan perbankan, karena tingkat pengembalian yang diharapkan investor juga akan tinggi. Sesuai dengan teori sinyal bahwa kenaikan nilai Economic Value Added (EVA) ialah sinyal positif atas naiknya harga saham perbankan. Hal ini berarti, terjadi peningkatan permintaan saham dari masyarakat sehingga nilai saham juga ikut mengalami peningkatan.

Hasil penelitian ini searah dengan hasil penelitian Thover (2018), Silalahi dan Tamba (2017) yang menyimpulkan bahwa variabel Economic Value Added (EVA) berpengaruh positif terhadap Harga Saham.

\section{Simpulandan saran}

Berlandaskan analisa serta uraian yang telah dipaparkan diatas, diperoleh simpulan yang bisa ditarik, yaitu : (1) adanya pengaruh negatif Non Performing Loan (NPL) terhadap Harga Saham, maka hipotesis pertama bisa diterima. Artinya, semakin tinggi nilai NPL mengakibatkan terjadinya penurunan harga saham. (2) adanya pengaruh negatif variabel Loan to deposit ratio (LDR) terhadap Harga Saham, artinya hipotesis kedua bisa diterima. Hal ini berarti pertumbuhan nilai LDR yang semakin tinggi akan berimbas pada turunnya harga saham. (3) adanya pengaruh negatif variabel Good Corporate Governance (GCG) terhadap Harga Saham, maka hipotesis ketiga bisa dibuktikan. Artinya kenaikan peringkat GCG akan berimbas pada turunnya harga saham bank . (4) adanya pengaruh positif variabel Net Interest Margin (NIM) terhadap Harga Saham, sehingga hipotesis keempat bisa diterima. Artinya pertumbuhan nilai NIM yang tinggi akan berimbas atas kenaikan harga saham. (5) terdapat pengaruh positif variabel Return On Asset (ROA) atas Harga Saham, maka hipotesis kelima bisa diterima. Artinya pertumbuhan nilai ROA yang tinggi akan berimbas atas naiknya harga saham. (6) Capital Adequacy Ratio (CAR) tidak berpengaruh terhadap Harga Saham, sehingga hipotesis keenam ditolak. (7) Adanya pengaruh positif variabel Economic Value Added (EVA) terhadap Harga Saham, maka hipotesis ketujuh bisa diterima. Artinya pertumbuhan nilai EVA yang tinggi akan berimbas pada naiknya harga saham. 
Berlandaskan hasil analisa serta simpulan yang telah dipaparkan diatas, adapun saran dari peneliti yaitu : pertama bagi pihak bank diharapkan dapat terus mempertahankan tingkat kesehatannya sesuai dengan regulasi dari BI. Dengan kondisi bank yang sehat maka kinerja perbankan juga akan meningkat. Dengan tingkat kesehatan serta kinerja yang baik, maka dapat membuat investor untuk memiliki saham perbankan, sehingga hal tersebut akan berimbas atas pertumbuhan harga saham perusahaan. Kedua, diharapkan untuk investor, sebelum mengambil keputusan investasi, sebaiknya perlu menganalisis tingkat kesehatan bank dengan baik dan hati-hati. Selain itu nilai perusahaan juga penting dianalisis oleh investor. Sehingga diketahui apakah perusahaan yang akan diinvestasikan memiliki nilai tambah ekonomi atau tidak, karena akan berpengaruh terhadap besarnya pengembalian yang diterima investor di kemudian hari. Ketiga, diharapkan bagi peneliti berikutnya dapat menggunakan faktor-faktor eksternal, seperti tingkat inflasi, kondisi ekonomi dan politik, dan faktor internal lainnya yang memiliki efek atas harga saham selain penggunaan atas variabel pada penelitian ini. Selain itu jumlah sampel perlu ditambahkan dan periode pengamatan juga perlu diperpanjang agar memperoleh hasil penelitian yang lebih akurat.

\section{Daftar Rujukan}

Afandi, David. (2017). Pengaruh Variabel Tingkat Kesehatan Bank Terhadap Harga Saham Pada Perusahaan Perbankan yang Terdaftar di Bursa Efek Indonesia Tahun 2011-2015 (Skripsi).Sekolah Tinggi Ilmu Ekonomi Widya Wiwaha.

Asrori, Edwin. (2017). Pengaruh Komponen Rgec Terhadap Harga Saham Perbankan Di Bursa Efek Indonesia Tahun 2014-2015. Naskah Publikasi, Universitas Muhammadiyah Surakarta.

Bank Indonesia. (2011). Peraturan Bank Indonesia nomor 13/1/PBI/2011 tentang Penilaian Tingkat Kesehatan Bank Umum. Jakarta: Bank Indonesia.

Cahyani, Desy, Wulandara. Putri, Asri, Dwija. (2018). Pengaruh Risk Profile, Good Corporate Governance, Earnings Dan Capital Pada Perubahan Harga Saham Bank. E-Jurnal Akuntansi Universitas Udayana , Vol.25: 959-987.

Fahlevi, Rido, Raiza. Set, Asmapane. Oktavianti. (2018). Pengaruh Kinerja Keuangan Terhadap Harga Saham Pada Perusahaan Perbankan yang Terdaftar di Bursa Efek Indonesia. Jurnal FEB Unmul. Akuntabel 15; 39-48.

Fauzziyah, Salma, Aulia. (2018). Pengaruh Kesehatan Bank Metode Rgec (Risk Profile, Good Corporate Governance, Earning, Dan Capital) Terhadap Harga Saham (Studi Pada Bank Umum Pemerintah Dan Bank Umum Swasta Devisa Yang Terdaftar Di Bursa Efek Indonesia (Skripsi). Fakultas Ekonomi dan Bisnis Unpas Bandung.

Febiolla, Destya. Winda Mulyani,. Hans, Andreas. (2019). Pengaruh Tingkat Kesehatan Perbankan terhadap Harga Saham Perusahaan Perbankan di BEI tahun 2008-2017. E-Journal Perspektif Akuntansi. Vol. 2 : 211-236.

Ghozali, Imam. (2011). "Aplikasi Analisis Multivariate Dengan Program SPSS”. Semarang: Badan Penerbit Universitas Diponegoro.

Kasmir. (2012). Bank dan Lembaga Keuangan Lainnya. Edisi Revisi. Jakara: PT Raja Grafindo Persada

Kasmir. (2012). Analisis Laporan Keuangan. Edisi Revisi. Jakarta; PT Rajagrafindo Persada.

Martaronika, Ninky. (2018). Pengaruh Loan To Deposit Ratio (Ldr), Non Performing Loan (Npl), Capital Adequacy Ratio (Car), Net Interest Margin (Nim) Terhadap Harga Saham Bank Umum Konvensional Yang Terdaftar Di Bursa Efek Indonesia Pada Tahun 2014-2016 (Skripsi). Universitas Negeri Yogyakarta.

Purnamasari, Diah. Elva, Nuraina. Elly, Astuti. (2017). Pengaruh Capital Adequacy Ratio, Loan To Deposit Ratio Dan Return On Asset Terhadap Harga Saham Perusahaan Perbankan. Vol. 5 No.1. Forum Ilmiah Pendidikan Akuntansi. Universitas PGRI Madiun.

Ramdhani, Farhatullaili. (2018). Pengaruh Loan To Deposit Ratio (Ldr), Non Performing Loan (Npl), Capital Adequacy Ratio (Car), Net Interest Margin (Nim) Terhadap Harga Saham Bank Umum Konvensional Yang Terdaftar Di Bursa Efek Indonesia Pada Tahun 2014-2016. Skripsi,Universitas Islam Negari Maulana Malik Ibrahim

Riyadi, Selamat. Setyawan, Arditya, Farid. (2018). Analisis Pengaruh Kinerja Keuangan Dan EPS Terhadap Harga Saham Bank Kategori BUKU 4 (Periode 2013-2017). Jurnal Perbanas. Vol. 3. No.1.

Santoso, Singgih. (2012). Statistik Parametik. Jakarta: PT Gramedia Pustaka Umum. 
Sari, Yolanda. Budi, Yanti. Liza, Zulbahri. (2018). Pengaruh Kinerja Keuangan Terhadap Harga Saham (Studi Pada Sub Sektor Perbankan BUMN di BEI tahun 2012-2016). Jurnal Manajemen dan Kewirausahaan. Vol; 9. No.1.

Setyawan, Aditya, Wira, Perdana. (2012). Pengaruh Komponen Risk Based Bank Rating Terhadap Harga Saham Perusahaan Perbankan Yang Go Public Di Bursa Efek Indonesia (Bei) Tahun 2008-2011. Universitas di Ponogoro.

Silalahi dan Tamba, (2017). Analisis Pengaruh Kinerja Keuangan Terhadap Harga Saham Bank Umum pada Bursa Efek Indonesia. Institutional Repository Universitas Bakrie.

Sugiyono. 2017. Metode Penelitian kuantitatif, Kualitatif dan R\&D. Bandung: Alfabeta

Suryono, Bambang. (2017). Pengaruh Pofitabilitas dan Economic Value Added Terhadap Harga Saham. Jurnal Ilmu Riset dan Akuntansi. Sekolah Tinggi Ilmu Ekonomi Indonesia Surabaya.

Thover, Mastor, Chris. (2018). Analisis Pengaruh EVA, MVA, Likuiditas, dan Firm Zize Terhadap Harga Saham (Studi Kasus Perusahaan Sektor Retail Yang Terdaftar di Bursa Efek Indonesia 2012-2016) (Skripsi). Presiden University.

https://investasi.kontan.co.id/news/saham-bank-turun-tajam Tahun 2018 diakses pada 20 januari 2020 pukul 12.30

https://investasi.kontan.co.id/news/banyak-diburu-asing-ini-rekomendasi-analis-untuk-sahamperbankan?page=all diakses pada 20 Januari 2020 pukul 13.00 